\title{
Synthesis, Structure of Borylmagnesium, and Its Reaction with Benzaldehyde to Form Benzoylborane
}

\author{
Makoto Yamashita, * Yuta Suzuki, Yasutomo Segawa, and Kyoko Nozaki*
}

*To whom correspondence should be addressed.

E-mail: makotoy@chembio.t.u-tokyo.ac.jp;nozaki@chembio.t.u-tokyo.ac.jp

\author{
Contents \\ S1-S5 Experimental Section \\ S6 Table S1 \\ S7-S8 Figures S1-S4 \\ S9-S1 $\quad{ }^{1} \mathrm{H},{ }^{11} \mathrm{~B}$, and ${ }^{13} \mathrm{C}$ NMR spectra of 3 inTHF- $d_{8}$ \\ S12-S15 $\quad{ }^{1} \mathrm{H},{ }^{11} \mathrm{~B},{ }^{13} \mathrm{C},{ }^{7} \mathrm{Li}$ NMR spectra of 4 inTHF- $d_{8}$ \\ S16 $\quad{ }^{7} \mathrm{Li}$ NMR spectrum of LiBr in THF-d \\ S17-S19 $\quad{ }^{1} \mathrm{H},{ }^{11} \mathrm{~B}$, and ${ }^{13} \mathrm{C}$ NMR spectra of 5 inTHF- $d_{8}$
}

General. All manipulations were carried out in the argon-filled glovebox (Miwa MFG). The ${ }^{1} \mathrm{H},{ }^{7} \mathrm{Li}\left\{{ }^{1} \mathrm{H}\right\},{ }^{11} \mathrm{~B}\left\{{ }^{1} \mathrm{H}\right\}$, and ${ }^{13} \mathrm{C}\left\{{ }^{1} \mathrm{H}\right\}$ NMR spectra were recorded on $500 \mathrm{MHz}$ spectrometer with residual protiated solvent for ${ }^{1} \mathrm{H}$, external $\mathrm{LiCl}$ in $\mathrm{D}_{2} \mathrm{O}$ for ${ }^{7} \mathrm{Li}\left\{{ }^{1} \mathrm{H}\right\}$, external $\mathrm{BF}_{3} \cdot \mathrm{OEt}_{2}$ for ${ }^{11} \mathrm{~B}\left\{{ }^{1} \mathrm{H}\right\}$, and deuterated solvent for ${ }^{13} \mathrm{C}\left\{{ }^{1} \mathrm{H}\right\}$ used as reference. THF, hexane, and pentane for the reaction of borylmagnesium were purified by passing through a solvent purification system (Grass Contour) and were further dried by stirring with $\mathrm{Na} / \mathrm{K}$ alloy at room temperature in the glovebox prior to use unless otherwise noted. THF- $d_{8}$ was dried by stirring with $\mathrm{Na} / \mathrm{K}$ alloy at room temperature in the glovebox prior to use. Lithium powder was made by washing commercial lithium oil dispersion with hexane.

Large scale synthesis of 1 . A suspension of $\left(2,6-(i-\mathrm{Pr})_{2} \mathrm{C}_{6} \mathrm{H}_{3}\right) \mathrm{N}=\mathrm{CHCH}=\mathrm{N}$ $\left(2,6-(i-P r){ }_{2} \mathrm{C}_{6} \mathrm{H}_{3}\right)(34.6 \mathrm{~g}, 91.9 \mathrm{mmol})$ and lithium granule $(1.89 \mathrm{~g}, 272 \mathrm{mmol})$ in ether $(400 \mathrm{~mL})$ was stirred at room temperature for 2 days under argon atmosphere to afford a dark yellow suspension. After removing excess lithium, $\mathrm{NEt}_{3} \mathrm{HCl}(26.2 \mathrm{~g}, 190 \mathrm{mmol})$ was added to the filtrate, and the resulting white suspension was stirred at room temperature for $1 \mathrm{~h}$. The suspension was filtered through a Celite ${ }^{\circledR}$ pad to remove excess $\mathrm{NEt}_{3} \mathrm{HCl}$, the solvent and $\mathrm{NEt}_{3}$ were evaporated and the resulting residue was dissolved in $\mathrm{CH}_{2} \mathrm{Cl}_{2}(100 \mathrm{ml}) . \mathrm{BBr}_{3}$ solution $\left(1 \mathrm{M} \mathrm{CH}_{2} \mathrm{Cl}_{2}, 100 \mathrm{~mL}, 100 \mathrm{mmol}\right)$ was added dropwise to the resulting solution at $0{ }^{\circ} \mathrm{C}$ and stirred at room temperature for $12 \mathrm{~h}$. Reaction was quenched with ${ }^{i} \operatorname{Pr}_{2} \operatorname{EtN}(28.2 \mathrm{~g}, 218 \mathrm{mmol})$, and the solvents and excess ${ }^{i} \operatorname{Pr}_{2}$ EtN were removed at reduced pressure. Hexane $(400 \mathrm{~mL})$ was added to the resulting residue, the suspension was filtered through a Celite ${ }^{\circledR}$ pad and the insoluble salts were washed with hexane. After volatiles ware removed from the filtrate, recrystallization of the residue from hexane at $-45^{\circ} \mathrm{C}$ gave colorless crystals of $1(32.9 \mathrm{~g}, 77 \%)$. Chemical propaties of the crystal was identical to 1 which we previously reported. ${ }^{\mathrm{S} 1}$ 
Preparation of stock solution A of boryllithium 2. In a glovebox, a $20 \mathrm{~mL}$ vial equipped with a glass magnetic stir bar was charged with $\mathbf{1}(2.01 \mathrm{~g}, 4.28 \mathrm{mmol}), \mathrm{Li}$ powder (149 mg, $21.4 \mathrm{mmol})$, and naphthalene $(274 \mathrm{mg}, 2.14 \mathrm{mmol})$. After cooling the vial to $-45^{\circ} \mathrm{C}$, THF $(10 \mathrm{~mL})$ was added to the vial. The resulting mixture was stirred for $12 \mathrm{~h}$ at $-45^{\circ} \mathrm{C}$. After a portion of the reaction mixture was monitored by ${ }^{11} \mathrm{~B}$ NMR to confirm the reaction was complete, the resulting mixture was filtered through a pad of Celite ${ }^{\circledR}$ and the residue was washed with THF to give stock solution A (boryllithium, $11.65 \mathrm{~g}, 4.28 \mathrm{mmol})$.

Preparation of THF- $\boldsymbol{d}_{\mathbf{8}}$ stock solution B of boryllithium 2. In a glovebox, a $4 \mathrm{~mL}$ vial equipped with a glass magnetic stir bar was charged with 1 (750 mg, $1.60 \mathrm{mmol})$, Li powder (57.1 mg, $8.23 \mathrm{mmol})$, and naphthalene (134 mg, $1.05 \mathrm{mmol})$. After cooling the vial to $-45^{\circ} \mathrm{C}$, THF- $d_{8}(3 \mathrm{~mL})$ was added to the vial. The resulting mixture was stirred for $12 \mathrm{~h}$ at $-45{ }^{\circ} \mathrm{C}$. The reaction mixture was filtered through a pad of Celite ${ }^{\circledR}$ and the residue was washed with THF- $d_{8}$. The filtrate was diluted to $5 \mathrm{~mL}$ with volumetric flask to give stock solution B (boryllithium, $0.320 \mathrm{M}$ in THF- $d_{8}$ ).

Preparation of stock solution C of boryllithium 2. In a glovebox, a $80 \mathrm{~mL}$ vial equipped with a glass magnetic stir bar was charged with 1 (3.59 g, $7.69 \mathrm{mmol})$, Li powder (267 mg, $38.5 \mathrm{mmol}$ ), and naphthalene (493 mg, $3.85 \mathrm{mmol})$. After cooling the vial to $-45{ }^{\circ} \mathrm{C}$, THF $(15 \mathrm{~mL})$ was added to the vial. The resulting mixture was stirred for $12 \mathrm{~h}$ at $-45^{\circ} \mathrm{C}$. After a portion of the reaction mixture was monitored by ${ }^{11} \mathrm{~B}$ NMR to confirm the reaction was complete, the resulting mixture was filtered through a pad of Celite ${ }^{\circledR}$ and the residue was washed with THF. The filtrate was diluted to $25 \mathrm{~mL}$ with volumetric flask to give stock solution C (boryllithium, $0.308 \mathrm{M}$ ).

Preparation of stock solution D of borylmagnesium bromide 3. In a glovebox, a 4 $\mathrm{mL}$ vial equipped with a glass stir bar was charged with an aliquot of stock solution $\mathbf{C}$ of boryllithium $2(0.308 \mathrm{M}, 0.955 \mathrm{~mL}, 0.294 \mathrm{mmol})$. To the vial, $\mathrm{MgBr}_{2} \cdot \mathrm{OEt}_{2}$ (77.5 mg, $0.300 \mathrm{mmol}$ ) was added as a solid and stirred vigorously at room temperature for 10 min. The resulting mixture was filtered through a pad of Celite ${ }^{\circledR}$ and the residue was washed with THF. The filtrate was diluted to $3 \mathrm{~mL}$ with volumetric flask to give stock solution D (borylmagnesium bromide, $0.0982 \mathrm{M}$ ).

Isolation of borylmagnesium bromide ( 3 and 4). In a glovebox, one quarter ( $2.91 \mathrm{~g}$, $1.07 \mathrm{mmol})$ of the stock solution A $(11.65 \mathrm{~g})$ was charged into a $20 \mathrm{~mL}$ vial equipped with a glass magnetic stir bar. To the solution of boryllithium, $\mathrm{MgBr}_{2} \cdot \mathrm{OEt}_{2}(276 \mathrm{mg}$, $1.07 \mathrm{mmol}$ ) was added as a solid and stirred vigorously at room temperature for $10 \mathrm{~min}$. After solvents were evaporated under reduced pressure, the residue was extracted with pentane and the solution was filtered through a pad of Celite ${ }^{\circledR}$ to remove inorganic salts. The crude product was recrystallized from pentane to give pale yellow crystals of $\mathbf{4}$ (independently characterized by X-ray analysis). After pipetted mother liquor out from the vial, the crystals were dissolved in pentane again and the resulting solution was filtered through a pad of Celite ${ }^{\circledR}$. Placing the filtrate at $-45{ }^{\circ} \mathrm{C}$ to give a mixture of colorless crystals of 3 (148 mg, 17\%) and pale yellow crystals of 4 (72.3 mg, 11\%). These crystals were easily separable by hand. These crystals were suitable for X-ray analysis (Figure S1 for 3 and Figure S2 for 4); 3: ${ }^{1} \mathrm{H}$ NMR (THF- $\left.d_{8}, 500 \mathrm{MHz}\right) \delta: 1.14$ 
$(J=7 \mathrm{~Hz}, \mathrm{~d}, 12 \mathrm{H}), 1.24(\mathrm{~J}=7 \mathrm{~Hz}, \mathrm{~d}, 12 \mathrm{H}), 1.76-1.79$ (m, 8H, THF), 3.40-3.46 (sep, $J=$ $7 \mathrm{~Hz}, 4 \mathrm{H}), 3.62$ (m, 8H, THF), 6.30 (s, 2H), 7.14-7.17 (m, 6H). ${ }^{11}$ B NMR (THF- $d_{8}, 160$ $\mathrm{MHz}) \delta 37.5$ (brs). ${ }^{13} \mathrm{C}$ NMR (THF-d, $\left.126 \mathrm{MHz}\right) \delta 24.6\left(\mathrm{CH}_{3}\right), 25.8\left(\mathrm{CH}_{3}\right), 26.6$ (THF), $29.1(\mathrm{CH}), 68.5(\mathrm{THF}), 121.2(\mathrm{NCH}), 123.7(\mathrm{CH}), 126.9(\mathrm{CH}), 145.5\left(4^{\circ}\right), 147.7$ (4 $\left.{ }^{\circ}\right)$ mp: $236.5-239.7{ }^{\circ} \mathrm{C}$ (dec.); 4: ${ }^{1} \mathrm{H}$ NMR (THF-d, $\left.500 \mathrm{MHz}\right) \delta 1.13$ (d, $J=7 \mathrm{~Hz}$, $12 \mathrm{H}), 1.24$ (d, $J=7 \mathrm{~Hz}, 12 \mathrm{H}), 1.77-1.78(\mathrm{~m}, 12 \mathrm{H}), 3.43$ (sept, $J=7 \mathrm{~Hz}, 4 \mathrm{H}), 3.60-3.63$ $(\mathrm{m}, 12 \mathrm{H}), 6.29(\mathrm{~s}, 4 \mathrm{H}), 7.13-7.18(\mathrm{~m}, 6 \mathrm{H}) .{ }^{7} \mathrm{Li}$ NMR $\left(\mathrm{THF}-\mathrm{d}_{8}, 194 \mathrm{MHz}\right) \delta 0.4(\mathrm{~s}) .{ }^{11} \mathrm{~B}$ NMR (THF-d, $160 \mathrm{MHz}) \delta 37.6$ (brs). ${ }^{13} \mathrm{C}$ NMR (THF-d, $\left.126 \mathrm{MHz}\right) \delta 24.6\left(\mathrm{CH}_{3}\right)$, $25.8\left(\mathrm{CH}_{3}\right), 26.6$ (THF), $29.1(\mathrm{CH}), 68.5(\mathrm{THF}), 121.2(\mathrm{NCH}), 123.7(\mathrm{CH}), 126.9(\mathrm{CH})$, $145.5\left(4^{\circ}\right), 147.7\left(4^{\circ}\right) . \mathrm{mp}: 254.6-258.2{ }^{\circ} \mathrm{C}$ (dec.); $\mathbf{L i B r}$ as a reference: ${ }^{7} \mathrm{Li}$ NMR $\left(\mathrm{THF}-d_{8}, 194 \mathrm{MHz}\right) \delta 0.4(\mathrm{~s})$.

Isolation of bis(boryl)magnesium (5). In a glovebox, one quarter (2.91 g, $1.07 \mathrm{mmol}$ ) of the stock solution A (11.65 g) was charged into a $20 \mathrm{~mL}$ vial equipped with a glass magnetic stir bar. To the solution of boryllithium, $\mathrm{MgBr}_{2} \cdot \mathrm{OEt}_{2}(138 \mathrm{mg}, 0.535 \mathrm{mmol})$ was added as a solid and stirred vigorously at room temperature for 12 hours. After solvents were evaporated under reduced pressure, the residue was extracted with pentane and the solution was filtered through a pad of Celite ${ }^{\circledR}$ to remove inorganic salts. The crude product was recrystallized from pentane to give pale yellow crystals of 5 (96.3 mg, 19\%). The crystals were suitable for X-ray analysis (Figure S3). ${ }^{1} \mathrm{H}$ NMR $\left(\mathrm{THF}-d_{8}, 500 \mathrm{MHz}\right) \delta 1.01(\mathrm{~d}, J=7 \mathrm{~Hz}, 24 \mathrm{H}), 1.06(\mathrm{~d}, J=7 \mathrm{~Hz}, 24 \mathrm{H}), 1.77-1.78(\mathrm{~m}$, $12 \mathrm{H}), 3.30$ (sept, $J=7 \mathrm{~Hz}, 8 \mathrm{H}), 3.60-3.63(\mathrm{~m}, 12 \mathrm{H}), 6.06$ (s, 4H), 7.07-7.13 (m, 12H). ${ }^{11} \mathrm{~B}$ NMR (THF- $\left.d_{8}, 160 \mathrm{MHz}\right) \delta 37.6$ (brs). ${ }^{13} \mathrm{C}$ NMR $\left(\mathrm{THF}-d_{8}, 126 \mathrm{MHz}\right) \delta 24.1\left(\mathrm{CH}_{3}\right)$, 26.7 (THF), $27.1\left(\mathrm{CH}_{3}\right), 28.9(\mathrm{CH}), 68.5(\mathrm{THF}), 122.3(\mathrm{NCH}), 124.0(\mathrm{CH}), 126.9(\mathrm{CH})$, $146.2\left(4^{\circ}\right), 147.6\left(4^{\circ}\right)$. Mp: $274.5-277.6^{\circ} \mathrm{C}$ (dec.).

${ }^{1} \mathrm{H}$ NMR monitoring the reaction of boryllithium 2 with 1.0 eq of $\mathrm{MgBr}_{2} \cdot \mathrm{OEt}_{2}$. In a glovebox, a $4 \mathrm{~mL}$ vial equipped with a glass stir bar was charged with 1 (54.3 mg, 0.116 $\mathrm{mmol})$, lithium powder $(8.1 \mathrm{mg}, 1.2 \mathrm{mmol})$, and naphthalene $(7.4 \mathrm{mg}, 0.058 \mathrm{mmol})$. After cooling the vial to $-45^{\circ} \mathrm{C}$, cooled THF- $d_{8}\left(-45^{\circ} \mathrm{C}\right)$ was added to the vial. The resulting mixture was stirred at $-45{ }^{\circ} \mathrm{C}$ for $12 \mathrm{~h}$. The reaction mixture was filtered through a pad of Celite ${ }^{\circledR}$ and the residue was washed with $0.5 \mathrm{~mL}$ of THF- $d_{8}$. To the filtrate (solution of 2), $\mathrm{MgBr}_{2} \cdot \mathrm{OEt}_{2}(30.0 \mathrm{mg}, 0.116 \mathrm{mmol}$ ) was added as a solid at room temperature and the resulting mixture was vigorously stirred for $10 \mathrm{~min}$ at room temperature. An aliquot of the resulting solution was transferred to a screw-cap NMR tube to take a ${ }^{1} \mathrm{H}$ NMR spectrum. An NMR yield of borylmagnesium bromide 3 was estimated as $90 \%$ from the integral ratio of $\mathrm{C}-\mathrm{H}$ protons of 5 -membered ring between 3 and protonated product 6 .

${ }^{1} \mathrm{H}$ NMR monitoring the reaction of boryllithium 2 with 0.5 eq of $\mathrm{MgBr}_{2} \cdot \mathrm{OEt}_{2}$. In a glovebox, a $4 \mathrm{~mL}$ vial equipped with a glass magnetic stir bar was charged with an aliquot of stock solution B of boryllithium $2(0.320 \mathrm{M}, 500 \mu \mathrm{L}, 0.160 \mathrm{mmol})$. After cooling the vial to $-45{ }^{\circ} \mathrm{C}$, THF- $d_{8}(1 \mathrm{~mL})$ was added to the vial. To the vial, $\mathrm{MgBr}_{2} \cdot \mathrm{OEt}_{2}(15.0 \mathrm{mg}, 0.0580 \mathrm{mmol})$ was added as a solid at room temperature and the resulting mixture was vigorously stirred for $24 \mathrm{~h}$ at room temperature. An aliquot of the resulting solution was transferred to a screw-cap NMR tube to take a ${ }^{1} \mathrm{H}$ NMR spectrum. An NMR yield of borylmagnesium bromide 3 was estimated as $32 \%$ from the integral 
ratio of $\mathrm{C}-\mathrm{H}$ protons of 5 -membered ring among $\mathbf{3}$, protonated product $\mathbf{6}$, and unreacted boryllithium 2 (3: $6: 2=32 \%: 36 \%: 32 \%)$.

Monitoring the reaction of 3 with 1-3 eq of benzaldehyde. In a glovebox, a $4 \mathrm{~mL}$ vial equipped with a glass stir bar was charged with THF $(1 \mathrm{~mL})$ and benzaldehyde (1.00-3.00 eq, 10.0-30.0 $\mu \mathrm{L}, 98.2-295 \mu \mathrm{mol})$. To the vial, an aliquot of stock solution $\mathbf{D}$ of borylmagnesium bromide $3(0.308 \mathrm{M}, 1.00 \mathrm{~mL}, 98.2 \mu \mathrm{mol})$ was added dropwise at room temperature. After the resulting mixture was stirred at room temperature for $3 \mathrm{~h}$, solvents were removed under reduced pressure. A solution of phenanthrene $(0.100 \mathrm{M}$, $0.500 \mathrm{~mL}, 50.0 \mu \mathrm{mol})$ in $\mathrm{C}_{6} \mathrm{D}_{6}$ and dodecane $(22.3 \mu \mathrm{L}, 98.2 \mu \mathrm{mol}$, as internal standard for GC) were added to the residue, and then an aliquot of the resulting solution was transferred to a screw-capped NMR tube to take a ${ }^{1} \mathrm{H}$ NMR spectrum. The NMR yields of benzoylborane 7 , ester $\mathbf{8}$, and protonated $\mathbf{6}$ were estimated from the integral ratio of $\mathrm{C}$-H protons of 5-membered ring in 7, 8, and $\mathbf{6}$ relative to the internal phenanthrene standard (7: $18 \%, 8: 18 \%, 6: 56 \%$ for 1 eq; 7: $34 \%, 8: 24 \%, 6: 32 \%$ for 2 eq; $7: 22 \%, 8$ : $40 \%, 6: 16 \%$ for $3 \mathrm{eq})$. To the solution in the screw-capped NMR tube, aqueous $\mathrm{HCl}$ $(1.0 \mathrm{M}, 15 \mu \mathrm{L}, 15 \mu \mathrm{mol})$ was added at room temperature. The resulting solution was analyzed by GC to estimate the GC yields of benzyl alcohol product 9 with the relative intensity of internal $n$-dodecane standard ( $27 \%$ for 1 eq; $47 \%$ for 2 eq; $57 \%$ for 3 eq).

Monitoring the reaction of 2 with 1 or 3 eq of benzaldehyde. In a glovebox, a $4 \mathrm{~mL}$ vial equipped with a glass stir bar was charged with THF $(1 \mathrm{~mL})$ and benzaldehyde (1.00 or $3.00 \mathrm{eq}, 10.0$ or $30.0 \mu \mathrm{L}, 98.2$ or $295 \mu \mathrm{mol}$ ). To the vial, an aliquot of stock solution C of boryllithium $2(0.308 \mathrm{M}, 0.319 \mathrm{~mL}, 98.2 \mu \mathrm{mol})$ was added dropwise at room temperature. After the resulting mixture was stirred at room temperature for $3 \mathrm{~h}$, solvents were removed under reduced pressure. A solution of phenanthrene $(0.100 \mathrm{M}$, $0.500 \mathrm{~mL}, 50.0 \mu \mathrm{mol})$ in $\mathrm{C}_{6} \mathrm{D}_{6}$ and $n$-dodecane $(22.3 \mu \mathrm{L}, 98.2 \mu \mathrm{mol}$, as internal standard for GC) were added to the residue, and then an aliquot of the resulting solution was transferred to a screw-capped NMR tube to take a ${ }^{1} \mathrm{H}$ NMR spectrum. The NMR yields of alcohol 10, ester 8, and protonated $\mathbf{6}$ were estimated from the integral ratio of $\mathrm{C}-\mathrm{H}$ protons of 5 -membered ring in $\mathbf{1 0}, \mathbf{8}$, and $\mathbf{6}$ relative to the internal phenanthrene standard (10: $81 \%, 8: 0 \%, 6: 6 \%$ for 1 eq; 10: $0 \%, 8: 51 \%, 6: 10 \%$ for 3 eq). To the solution in the screw-capped NMR tube, aqueous $\mathrm{HCl}(1.0 \mathrm{M}, 15 \mu \mathrm{L}, 15 \mu \mathrm{mol})$ was added at room temperature. The resulting solution was analyzed by $\mathrm{GC}$ to estimate the GC yields of benzyl alcohol product 9 with the relative intensity of internal $n$-dodecane standard (9: $0 \%$ for $1 \mathrm{eq} ; 9$ : $50 \%$ for $3 \mathrm{eq})$.

Independent synthesis of acylborane 7 by the reaction of 2 with benzoyl chloride. In a glovebox, a $20 \mathrm{~mL}$ vial equipped with a glass magnetic stir bar was charged with an aliquot of stock solution $\mathbf{C}$ (boryllithium $2,10.0 \mathrm{~mL}, 3.08 \mathrm{mmol}$ ). To the vial, benzoyl chloride (649 mg, $4.61 \mathrm{mmol}$ ) was added dropwise at room temperature, and then the reaction mixture was stirred for $12 \mathrm{~h}$ at room temperature. After removing all volatiles, the crude product was purified by silica gel chlomatography with hexane : $\mathrm{CH}_{2} \mathrm{Cl}_{2}=3$ : 1 eluent to give yellow solids (856 mg, 57\%). ${ }^{1} \mathrm{H}$ NMR $\left(\mathrm{C}_{6} \mathrm{D}_{6}, 500 \mathrm{MHz}\right) \delta 1.19(\mathrm{~d}, J=$ $7 \mathrm{~Hz}, 12 \mathrm{H}), 1.26$ (d, $J=7 \mathrm{~Hz}, 12 \mathrm{H}), 3.40$ (sept, $J=7 \mathrm{~Hz}, 4 \mathrm{H}), 6.26$ (s, 2H), 6.88-6.96 $(\mathrm{m}, 3 \mathrm{H}), 7.028(\mathrm{~d}, J=9 \mathrm{~Hz}, 2 \mathrm{H}), 7.030(\mathrm{~d}, J=7 \mathrm{~Hz}, 2 \mathrm{H}), 7.08(\mathrm{dd}, J=9,7 \mathrm{~Hz}, 2 \mathrm{H})$, 7.76-7.79 (m, 2H). ${ }^{11} \mathrm{~B}$ NMR $\left(\mathrm{C}_{6} \mathrm{D}_{6}, 160 \mathrm{MHz}\right) \delta 21.8$ (brs). ${ }^{13} \mathrm{C} \mathrm{NMR}\left(\mathrm{C}_{6} \mathrm{D}_{6}, 126 \mathrm{MHz}\right)$ 
$\delta 23.5\left(\mathrm{CH}_{3}\right), 25.9\left(\mathrm{CH}_{3}\right), 28.8(\mathrm{CH}), 120.2(\mathrm{NCH}), 123.8(\mathrm{CH}), 128.1(\mathrm{CH}), 128.3$ $(\mathrm{CH}), 128.5(\mathrm{CH}), 132.4(\mathrm{CH}), 137.9\left(4^{\circ}\right), 141.8\left(4^{\circ}\right), 145.9\left(4^{\circ}\right), 218.7(\mathrm{br}, \mathrm{C}=\mathrm{O})$; IR $(\mathrm{KBr}): v_{\mathrm{CO}}=1618 \mathrm{~cm}^{-1}$; mp: $126.7-128.5{ }^{\circ} \mathrm{C}$ (dec.); Anal. Calcd for $\mathrm{C}_{33} \mathrm{H}_{41} \mathrm{BN}_{2} \mathrm{O}: \mathrm{C}$, $80.48 ; \mathrm{H}, 8.39 ; \mathrm{N}, 5.69$. Found: $\mathrm{C}, 80.51 ; \mathrm{H}, 8.61 ; \mathrm{N}, 5.50$.

Independent synthesis of borylester 8 by the reaction of 2 with 5 eq of PhCHO. In a glovebox, a $4 \mathrm{~mL}$ vial equipped with a glass stir bar was charged with $\mathrm{PhCHO}(204 \mu \mathrm{L}$, $2.00 \mathrm{mmol})$. To the vial, an aliquot of stock solution $\mathrm{C}$ of boryllithium $2(0.308 \mathrm{M}, 1.30$ $\mathrm{mL}, 0.400 \mathrm{mmol}$ ) was added dropwise at room temperature. After the reaction mixture was stirred at room temperature for $1 \mathrm{~h}$, solvents were evaporated under reduced pressure. $\mathrm{CHCl}_{3}$ was added to the residue and the resulting solution was subjected to recycle GPC with $\mathrm{CHCl}_{3}$ eluent to give a gummy yellow solids of borylester $\mathbf{8}\left(\mathrm{R}_{\mathrm{T}}=51\right.$ min, $105 \mathrm{mg}, 44 \%) .{ }^{1} \mathrm{H}$ NMR $\left(\mathrm{C}_{6} \mathrm{D}_{6}, 500 \mathrm{MHz}\right) \delta: 0.84(\mathrm{~d}, J=7 \mathrm{~Hz}, 6 \mathrm{H}), 1.10(\mathrm{~d}, J=7$ $\mathrm{Hz}, 6 \mathrm{H}), 1.18$ (d, $J=7 \mathrm{~Hz}, 6 \mathrm{H}), 1.45$ (d, $J=7 \mathrm{~Hz}, 6 \mathrm{H}), 2.97$ (sep, $J=7 \mathrm{~Hz}, 2 \mathrm{H}), 3.45$ (sep, $J=7 \mathrm{~Hz}, 2 \mathrm{H}), 6.17(\mathrm{~s}, 2 \mathrm{H}), 6.61(\mathrm{~s}, 1 \mathrm{H}), 6.82-6.86(\mathrm{~m}, 1 \mathrm{H}), 6.89-6.94(\mathrm{~m}, 4 \mathrm{H})$, 6.97-7.08 (m, 5H), 7.20-7.24 (m, 4H), 7.33-7.36 (m, 2H). ${ }^{11} \mathrm{~B}$ NMR $\left(\mathrm{C}_{6} \mathrm{D}_{6}, 160 \mathrm{MHz}\right) \delta$ 25.3 (brs). ${ }^{13} \mathrm{C}$ NMR $\left(\mathrm{C}_{6} \mathrm{D}_{6}, 126 \mathrm{MHz}\right) \delta 22.6\left(\mathrm{CH}_{3}\right), 23.2\left(\mathrm{CH}_{3}\right), 26.0\left(\mathrm{CH}_{3}\right), 26.2$ $\left(\mathrm{CH}_{3}\right), 28.7(\mathrm{CH}), 28.9(\mathrm{CH}), 68.9(\mathrm{br}, \mathrm{CH}), 120.5(\mathrm{NCH}), 123.7(\mathrm{CH}), 124.0(\mathrm{CH})$, $126.9(\mathrm{CH}), 127.8(\mathrm{CH}), 127.9(\mathrm{CH}), 128.0(\mathrm{CH}), 128.3(\mathrm{CH}), 128.4(\mathrm{CH}), 130.1(\mathrm{CH})$, $131.0\left(4^{\circ}\right), 132.3(\mathrm{CH}), 139.3(\mathrm{CH}), 141.3\left(4^{\circ}\right), 145.9\left(4^{\circ}\right), 146.4\left(4^{\circ}\right), 165.9(\mathrm{C}=\mathrm{O})$; IR $(\mathrm{KBr}): v_{\mathrm{CO}}=1719 \mathrm{~cm}^{-1}$; Anal. Calcd for $\mathrm{C}_{40} \mathrm{H}_{47} \mathrm{BN}_{2} \mathrm{O}_{2}: \mathrm{C}, 80.26 ; \mathrm{H}, 7.91 ; \mathrm{N}, 4.68$. Found: C, 80.00; H, 8.19; N, 4.49.

X-ray Crystallography. Details of the crystal data and a summary of the intensity data collection parameters for 3, 4, 5, and 7 are listed in Table S1. In each case a suitable crystal was mounted with a mineral oil to the glass fiber and transferred to the goniometer of a Rigaku Mercury CCD diffractometer with graphite-monochromated Mo $\mathrm{K} \alpha$ radiation $(\lambda=0.71073 \AA)$. The structures were solved by direct methods with $\left(\right.$ SIR97) ${ }^{\mathrm{S2}}$ and refined by full-matrix least-squares techniques against $F^{2}$ (SHELXL-97). ${ }^{\text {S3 }}$ The intensities were corrected for Lorentz and polarization effects. The non-hydrogen atoms were refined anisotropically. Hydrogen atoms were placed using AFIX instructions. Graphics were generated by the use of Pov-ray 3.5 software.

\section{References}

(S1) Segawa, Y.; Yamashita, M.; Nozaki, K. Science 2006, 314, 113-115.

(S2) Altomare, A.; Burla, M. C.; Camalli, M.; Cascarano, G. L.; Giacovazzo, C.; Guagliardi, A.; Moliterni, A. G. G.; Polidori, G.; Spagna, R. J. Appl. Cryst. 1999, 32, 115-119.

(S3) Sheldrick, G. M. SHELXL-97, Program for the Refinement of Crystal Structures; University of Göttingen, Göttingen, Germany, 1997. 
Table S1. Crystallographic data and structure refinement details for 3, 4, 5, and 7.

\begin{tabular}{|c|c|c|c|c|}
\hline & 3 & 4 & 5 & 7 \\
\hline formula & $\mathrm{C}_{34} \mathrm{H}_{52} \mathrm{BBrMgN}_{2} \mathrm{O}_{2}$ & $\mathrm{C}_{38} \mathrm{H}_{60} \mathrm{BBr}_{2} \mathrm{LiMgN}_{2} \mathrm{O}_{3}$ & $\mathrm{C}_{60} \mathrm{H}_{88} \mathrm{~B}_{2} \mathrm{MgN}_{4} \mathrm{O}_{2}$ & $\mathrm{C}_{33} \mathrm{H}_{41} \mathrm{BN}_{2} \mathrm{O}$ \\
\hline fw & 635.81 & 794.76 & 943.27 & 492.49 \\
\hline $\mathrm{T}(\mathrm{K})$ & $103(2)$ & $103(2)$ & $103(2)$ & $103(2)$ \\
\hline$\lambda(\AA)$ & 0.71073 & 0.71073 & 0.71073 & 0.71073 \\
\hline cryst syst & Orthorhombic & Orthorhombic & Orthorhombic & Monoclinic \\
\hline space group & $P 2{ }_{1} 2_{1} 2_{1}$ & $\mathrm{PCa}_{1}$ & $F d d 2$ & $P 2_{1} / \mathrm{a}$ \\
\hline$a,(\AA)$ & $13.305(6)$ & $26.5116(15)$ & $25.376(2)$ & $12.660(6)$ \\
\hline$b,(\AA)$ & $13.785(6)$ & $10.9036(9)$ & $41.133(5)$ & $15.480(8)$ \\
\hline$c,(\AA)$ & $19.459(8)$ & $28.9821(17)$ & $10.9179(11)$ & $14.755(7)$ \\
\hline$\beta,\left(^{\circ}\right)$ & & & & $90.479(2)$ \\
\hline$V,\left(\AA^{3}\right)$ & $3569(3)$ & $8377.9(10)$ & $11396(2)$ & $2892(2)$ \\
\hline$Z$ & 4 & 8 & 8 & 4 \\
\hline $\mathrm{D}_{\text {calc }},\left(\mathrm{g} / \mathrm{cm}^{3}\right)$ & 1.183 & 1.260 & 1.100 & 1.131 \\
\hline$\mu\left(\mathrm{mm}^{-1}\right)$ & 1.199 & 1.985 & 0.075 & 0.067 \\
\hline $\mathrm{F}(000)$ & 1352 & 3328 & 4112 & 1064 \\
\hline cryst size (mm) & $0.45 \times 0.25 \times 0.15$ & $0.55 \times 0.50 \times 0.20$ & $0.70 \times 0.70 \times 0.55$ & $0.65 \times 0.45 \times 0.25$ \\
\hline \multirow[t]{2}{*}{$2 \theta$ range, $(\mathrm{deg})$} & $3.06-25.00$ & $3.05-25.00$ & $3.09-26.50$ & $3.06-25.00$ \\
\hline & $-15<=\mathrm{h}<=15$ & $-31<=\mathrm{h}<=31$ & $-29<=\mathrm{h}<=31$ & $-15<=\mathrm{h}<=13$ \\
\hline \multirow[t]{2}{*}{ Index ranges } & $-13<=\mathrm{k}<=16$ & $-12<=\mathrm{k}<=12$ & $-47<=\mathrm{k}<=51$ & $-18<=\mathrm{k}<=17$ \\
\hline & $-22<=1<=23$ & $-34<=1<=34$ & $-9<=1<=13$ & $-17<=1<=17$ \\
\hline reflns collected & 23442 & 64043 & 24563 & 18257 \\
\hline indep reflns $/ R_{\text {int }}$ & $6279 / 0.0623$ & $14693 / 0.0602$ & $2960 / 0.0427$ & $4990 / 0.0414$ \\
\hline params & 483 & 933 & 295 & 342 \\
\hline GOF on $F^{2}$ & 1.142 & 1.143 & 1.156 & 1.122 \\
\hline$R_{1}, \mathrm{w} R_{2}[\mathrm{I}>2 \sigma(\mathrm{I})]$ & $0.0741,0.1301$ & $0.0509,0.0928$ & $0.0695,0.1795$ & $0.0572,0.1295$ \\
\hline$R_{1}, \mathrm{w} R_{2}$ (all data) & $0.0892,0.1365$ & $0.0566,0.0948$ & $0.0702,0.1799$ & $0.0782,0.1415$ \\
\hline Peak and hole $\left(\mathrm{e} . \AA^{-3}\right)$ & $0.397,-0.414$ & $0.753,-0.682$ & $0.575,-0.343$ & $0.203,-0.164$ \\
\hline
\end{tabular}


Figure S1. ORTEP drawing of 3 (50\% thermal ellipsoids, hydrogen atoms and minor parts of disordered isopropyl groups and bromine atom were omitted for clarity).

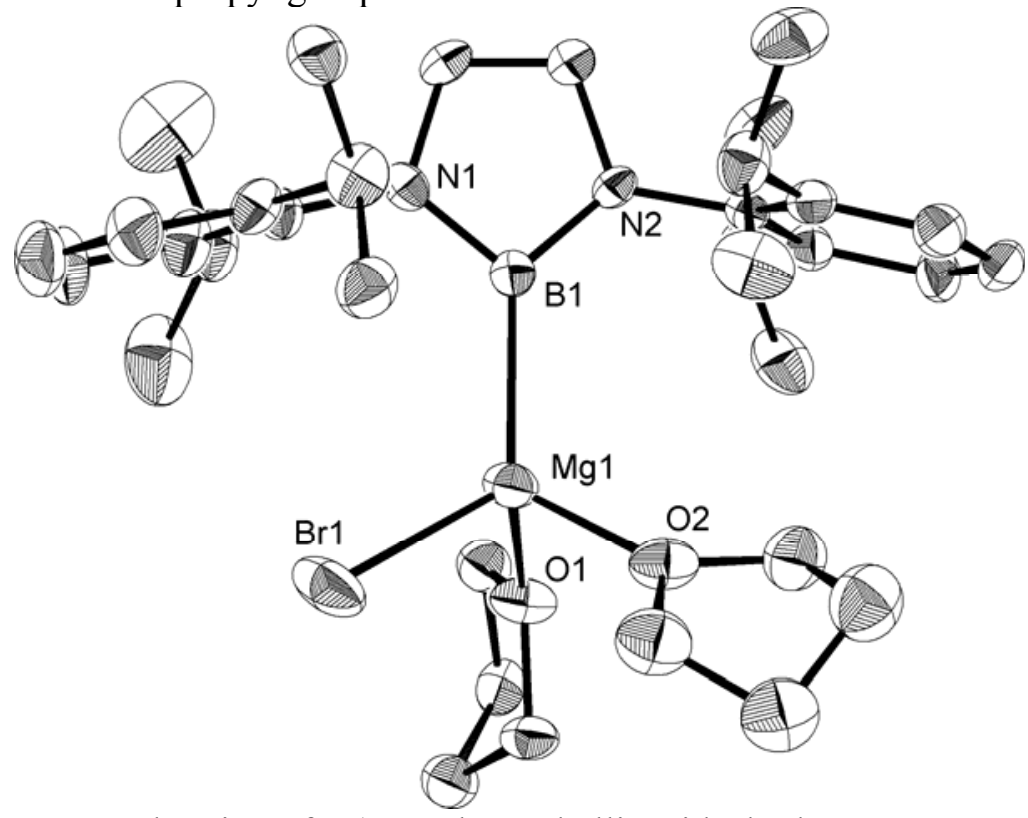

Figure S2. ORTEP drawing of 4 (50\% thermal ellipsoids, hydrogen atoms and a minor part of disordered isopropyl groups were omitted for clarity. One of two independent molecules is illustrated).

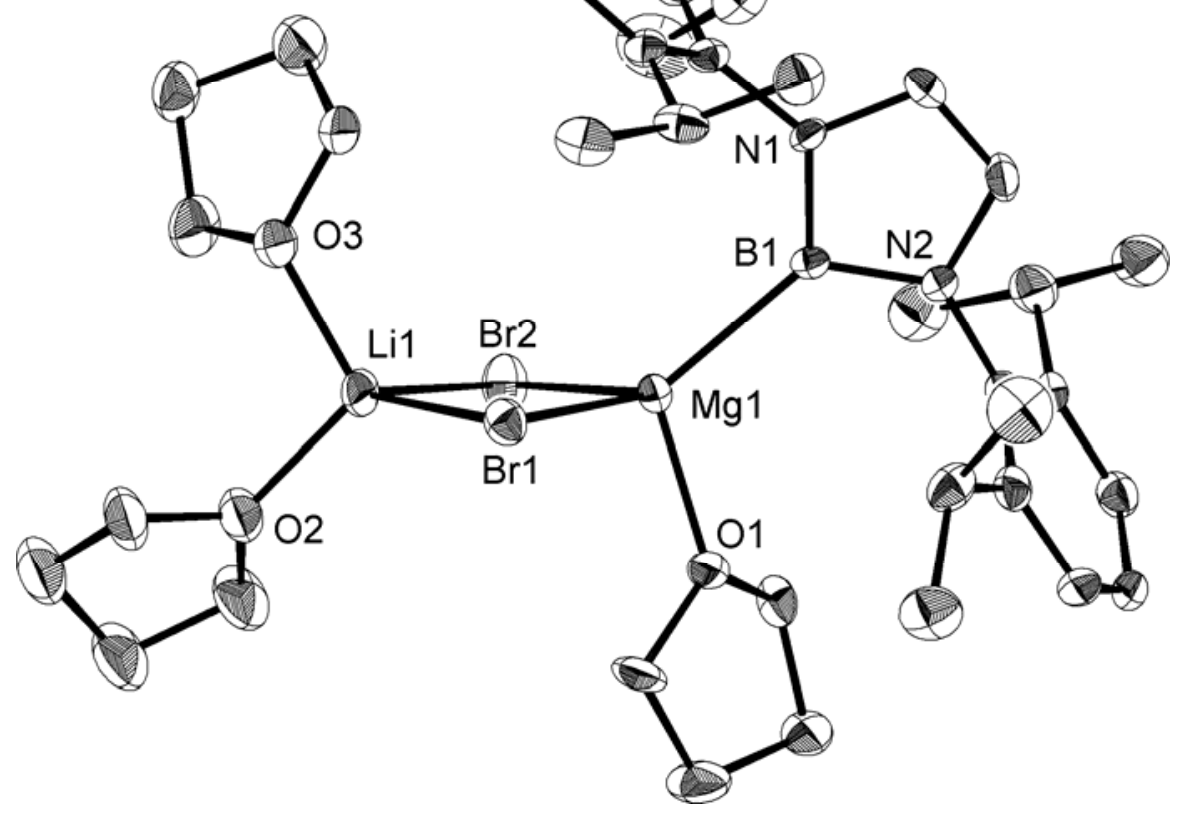


Figure S3. ORTEP drawing of 5 (50\% thermal ellipsoids, hydrogen atoms and a minor part of disordered isopropyl groups and THF molecule were omitted for clarity).

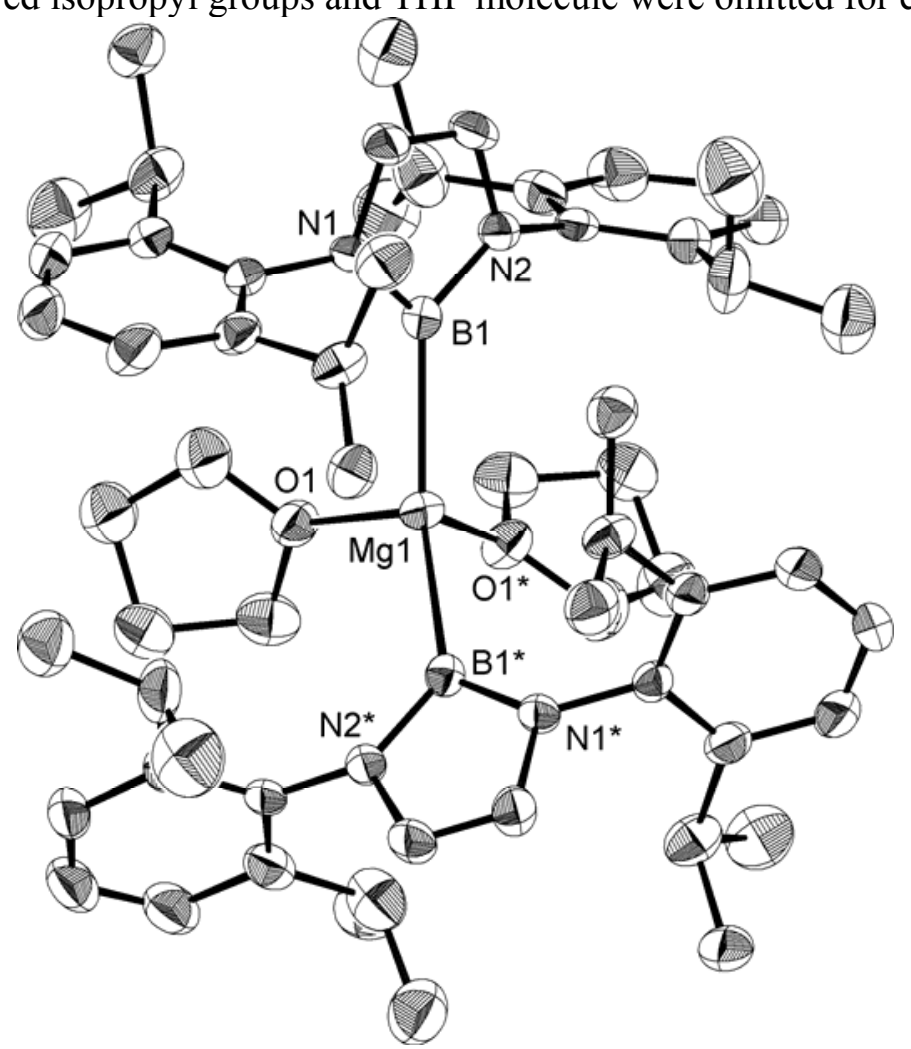

Figure S4. ORTEP drawing of 7 (50\% thermal ellipsoids, hydrogen atoms were omitted for clarity).

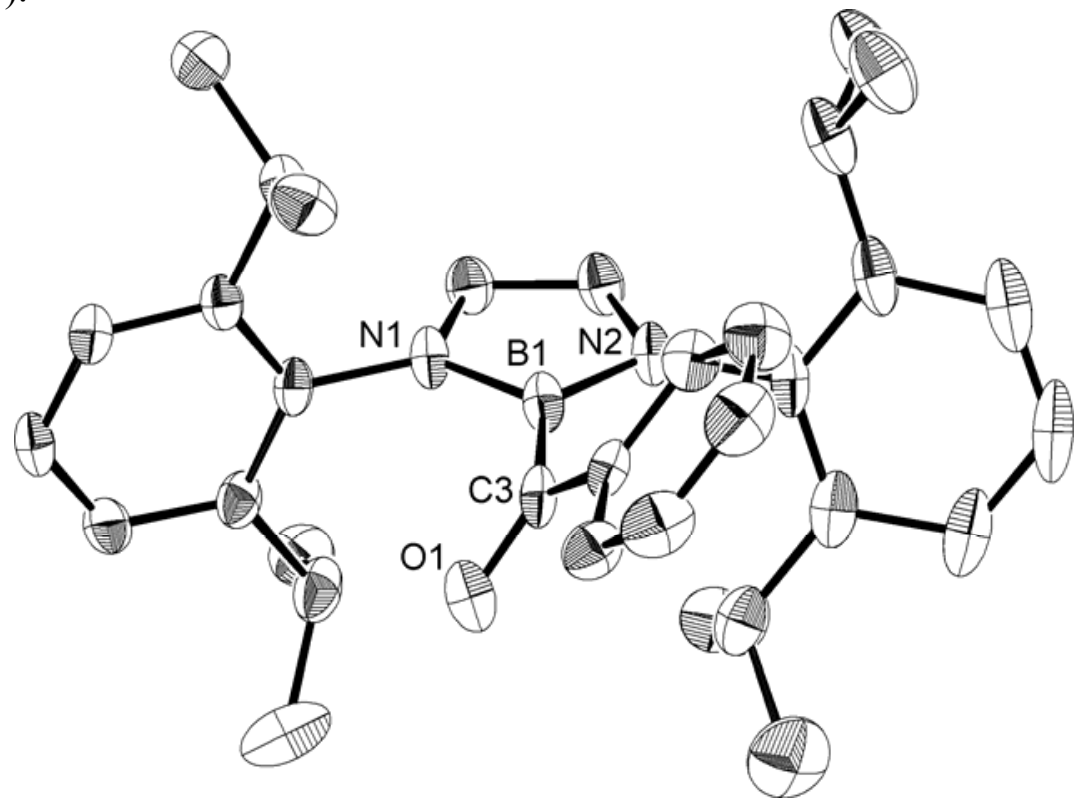



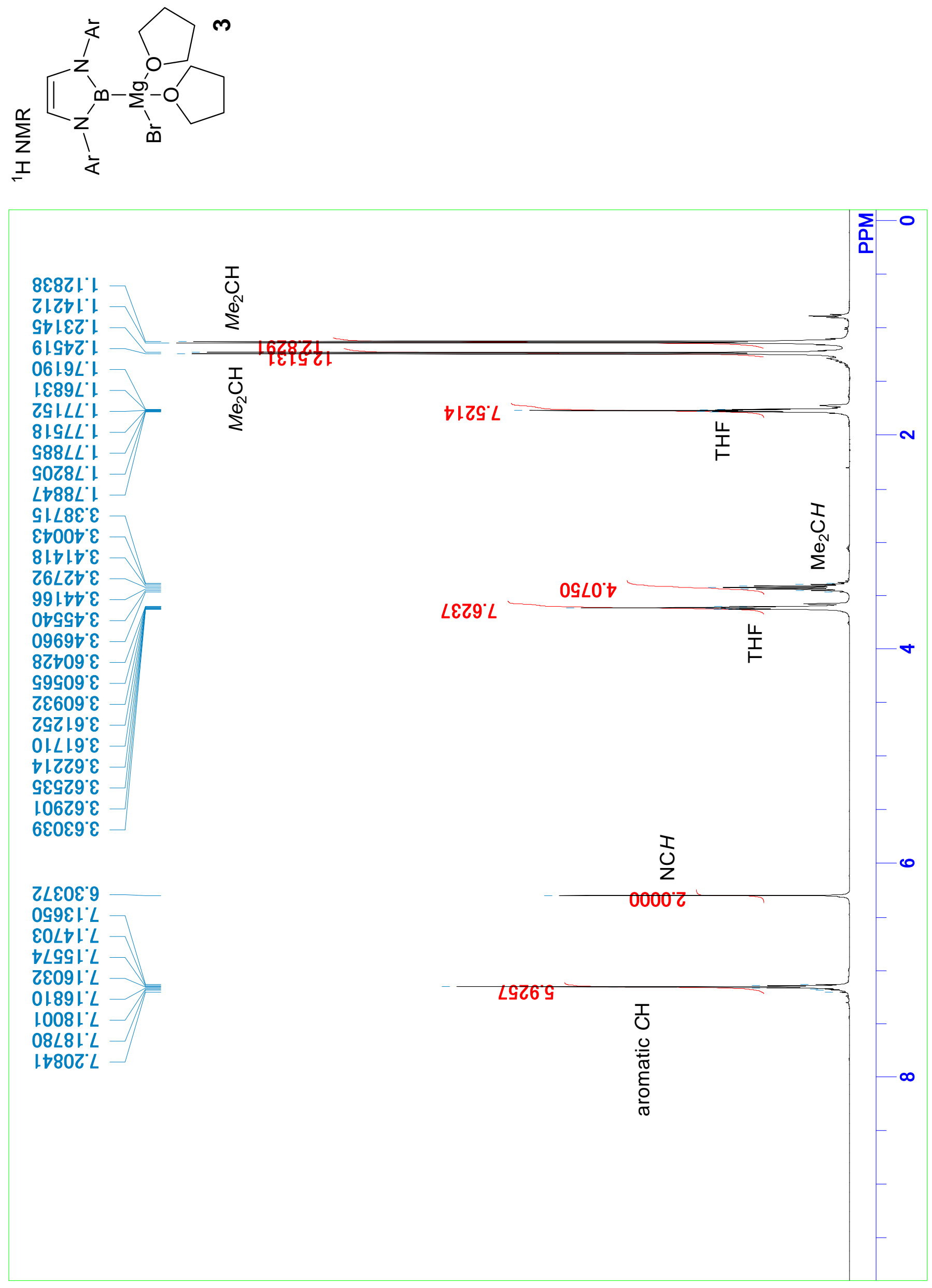

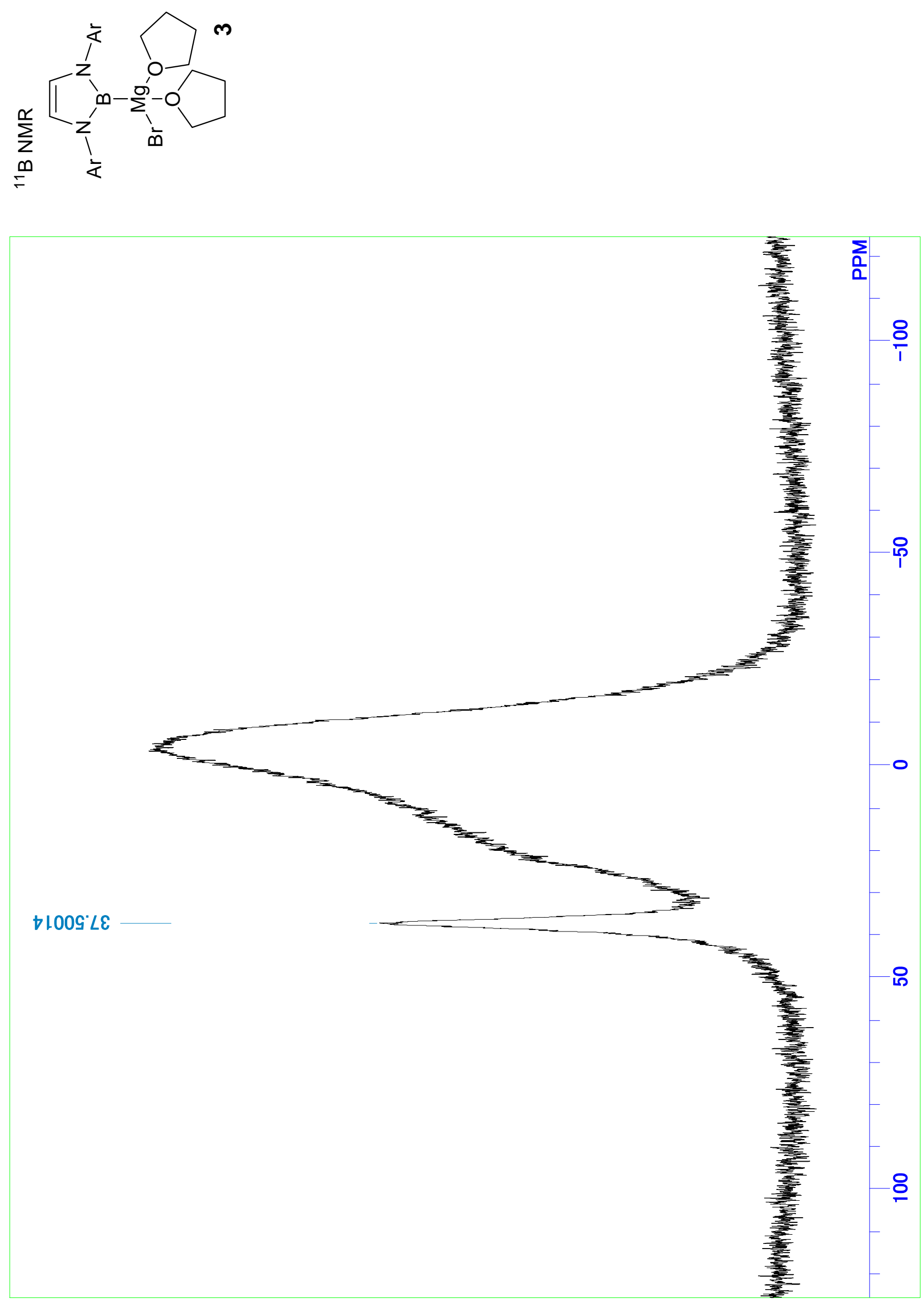

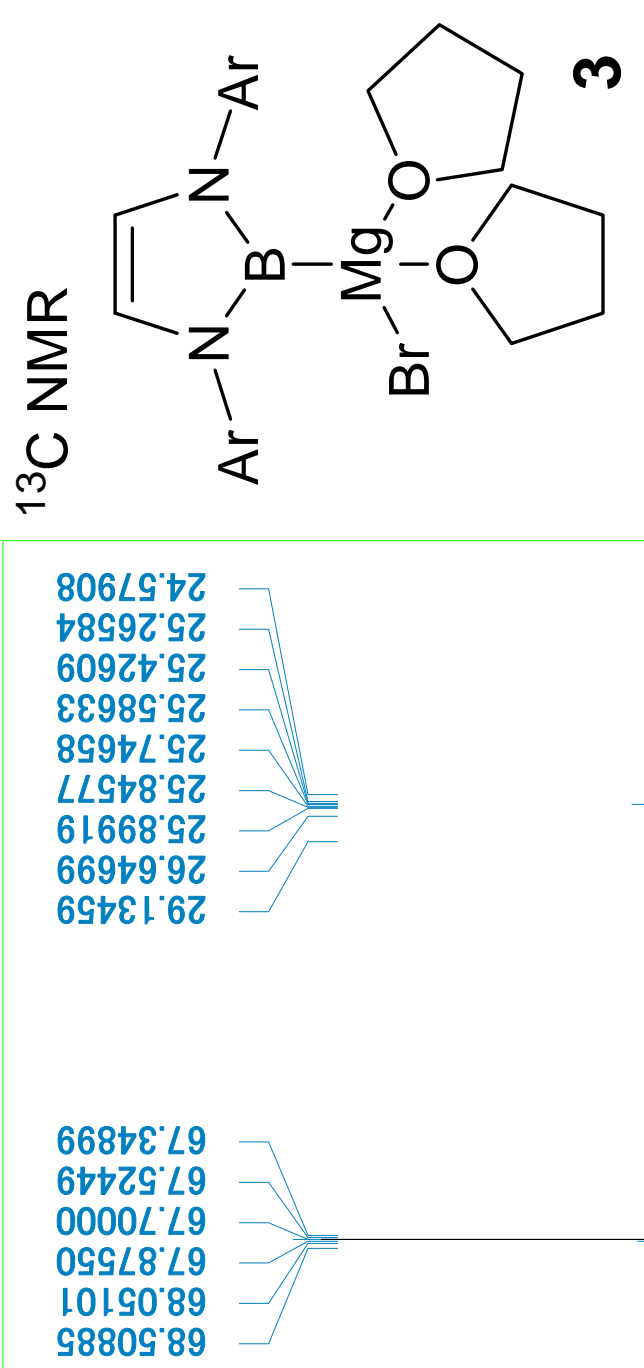

†8ZGเ"にて

เ $60 L$ LZL

9\&906.9Zよ

$$
x^{2}
$$

- 

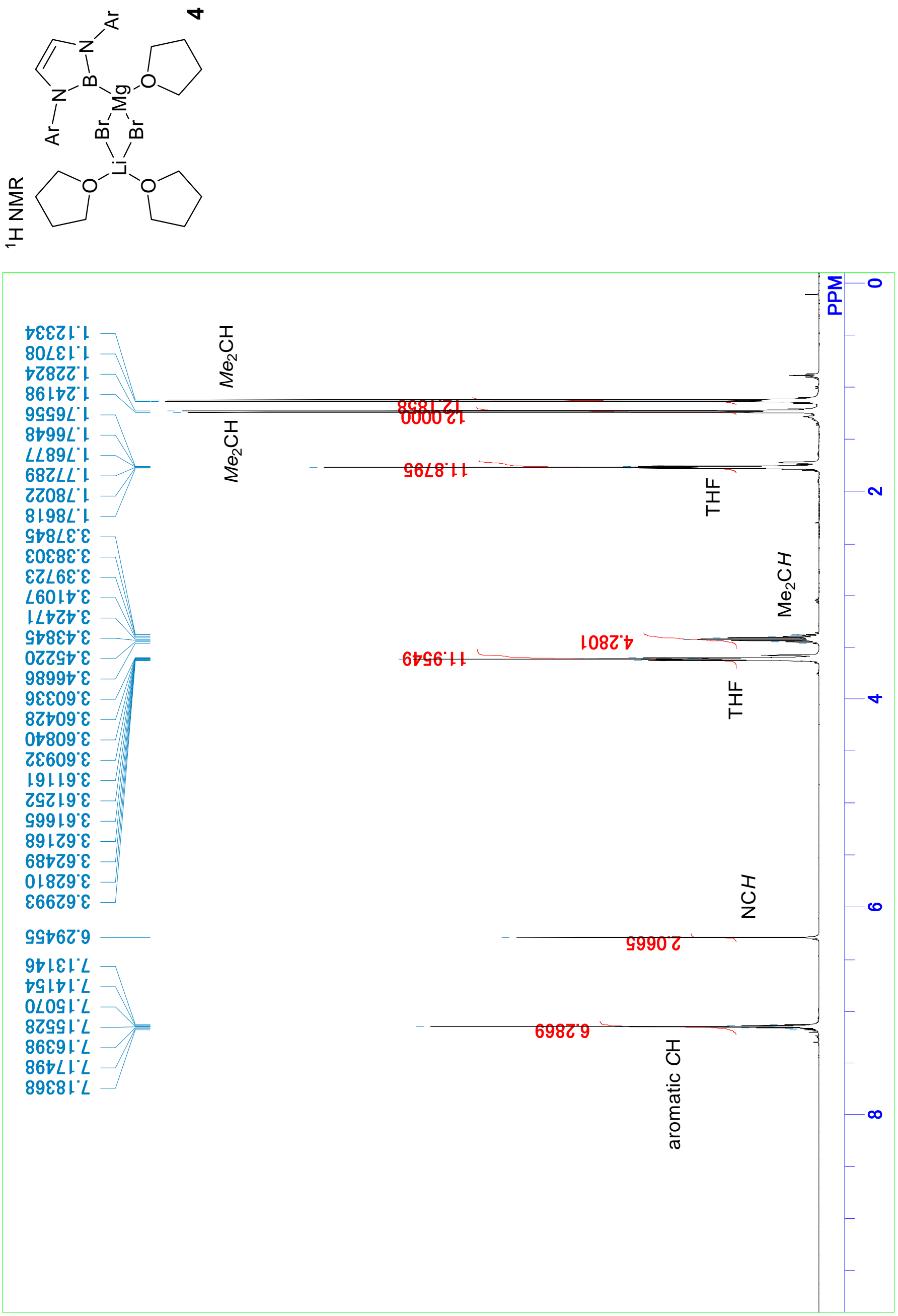

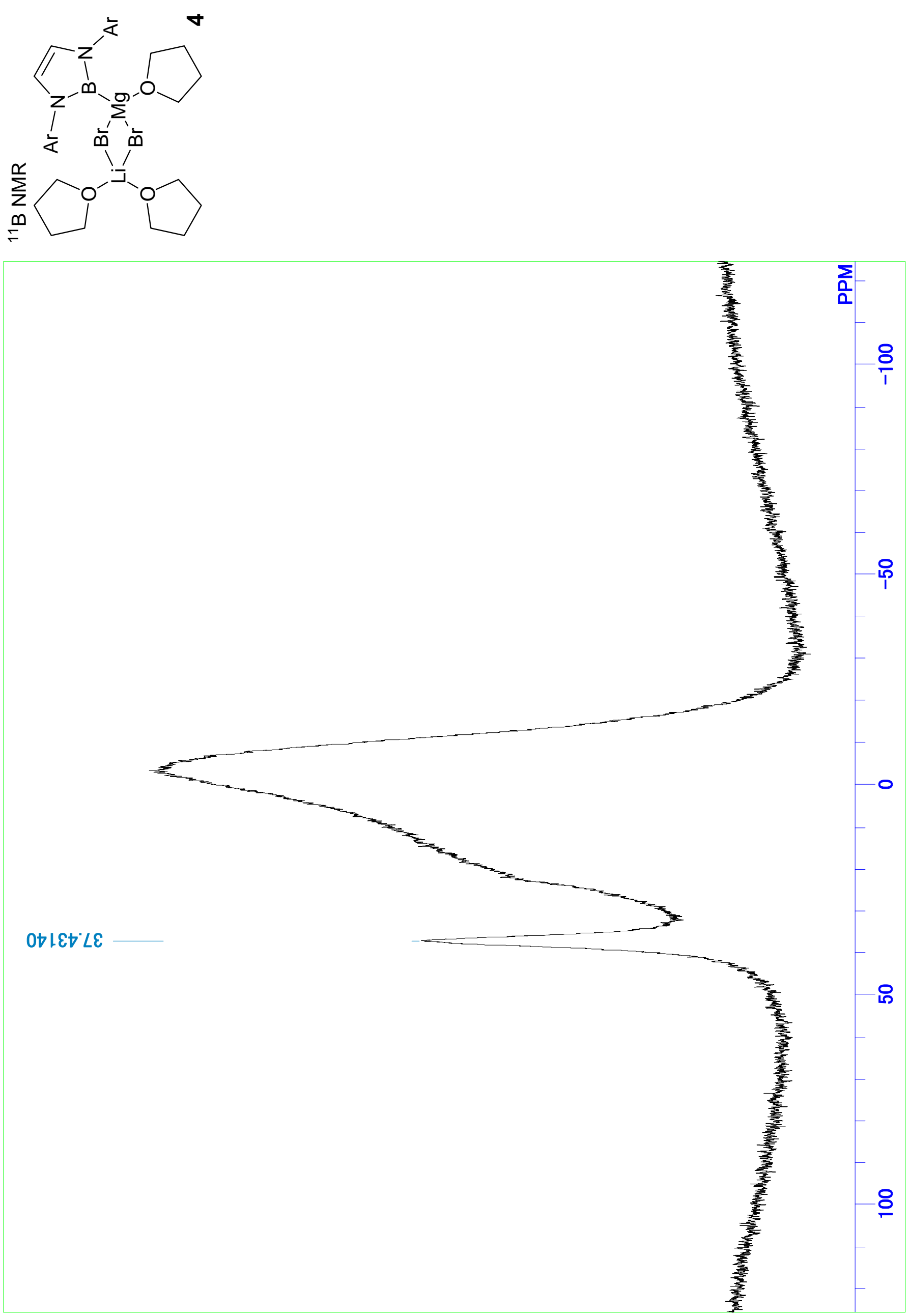

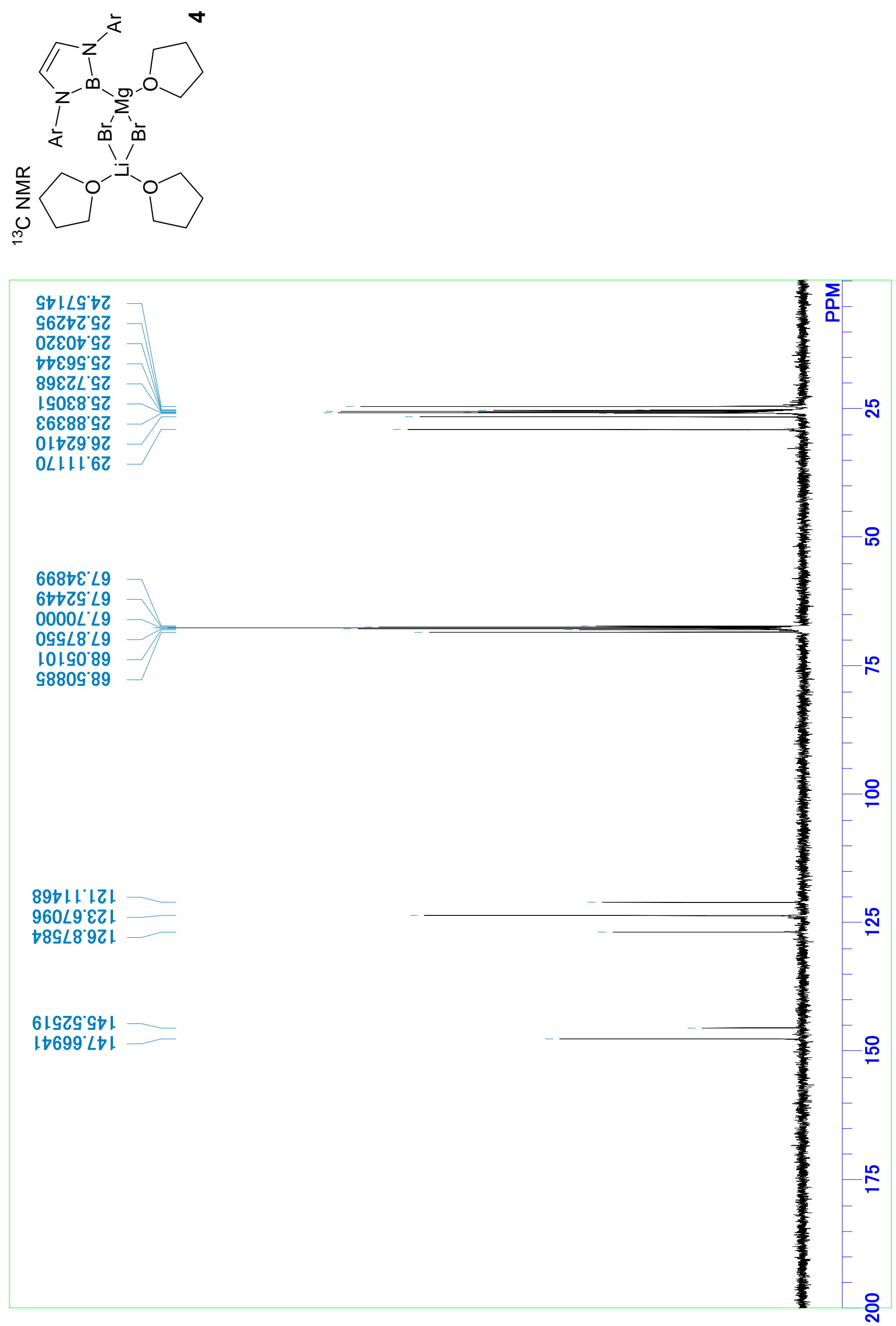

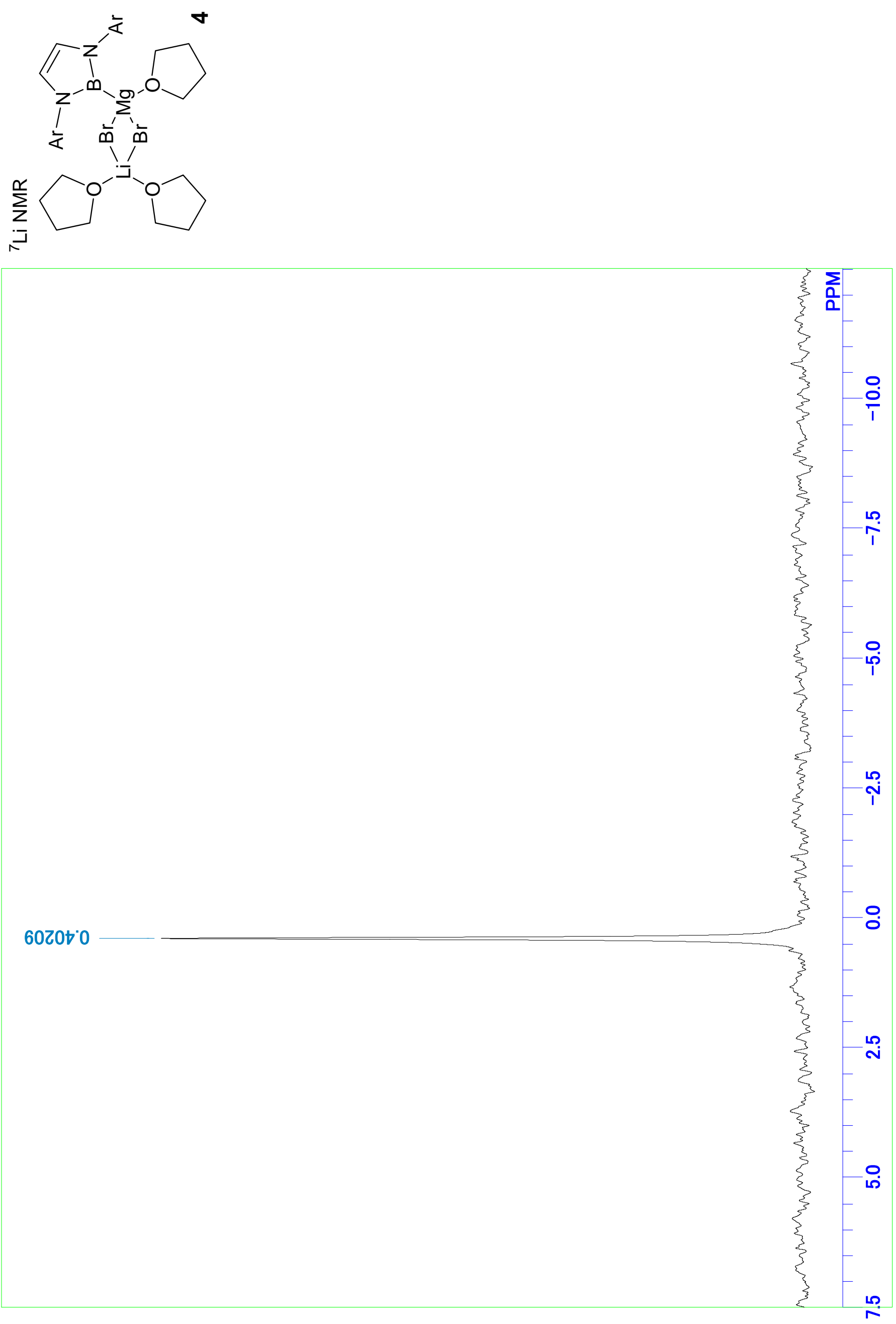

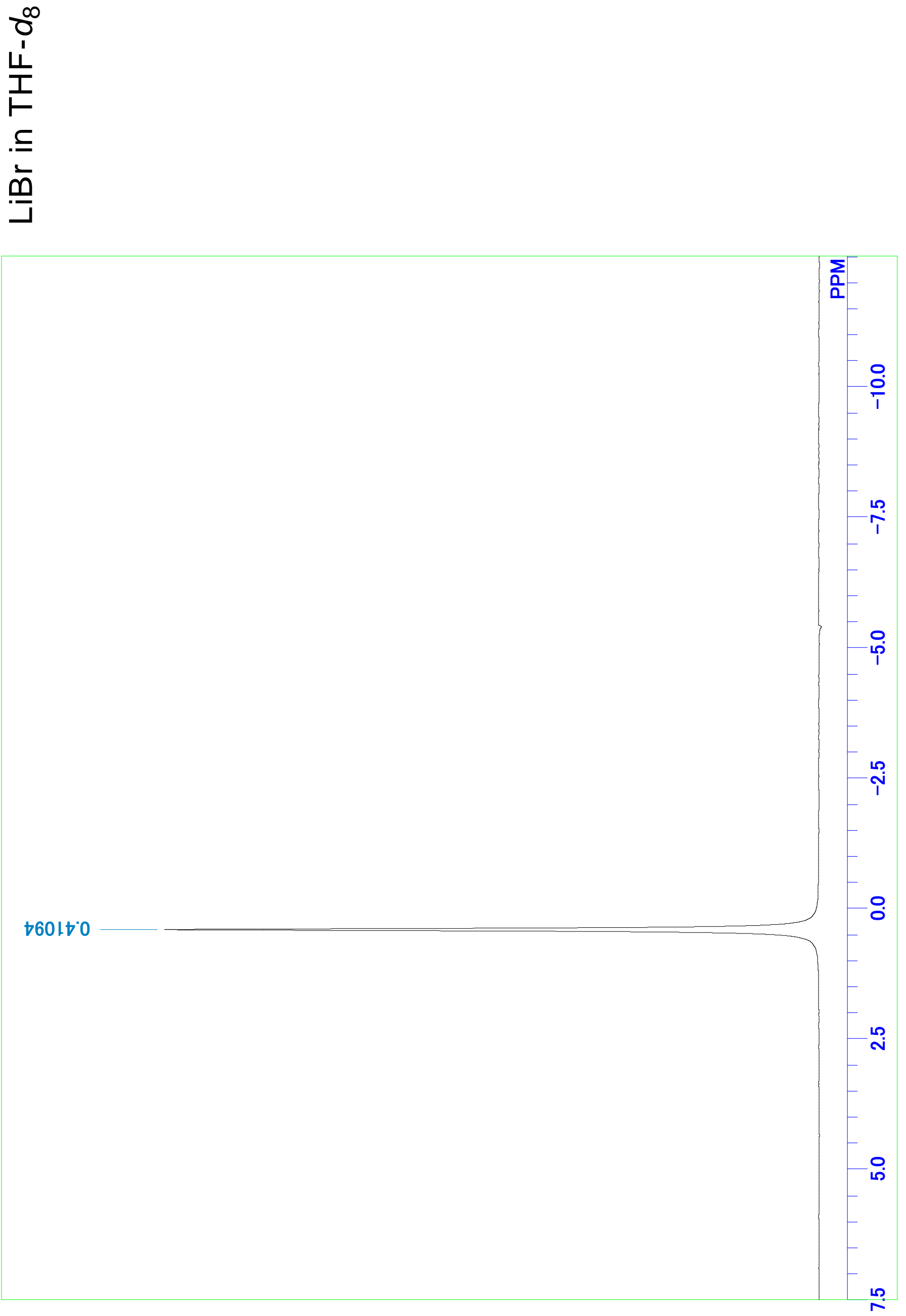

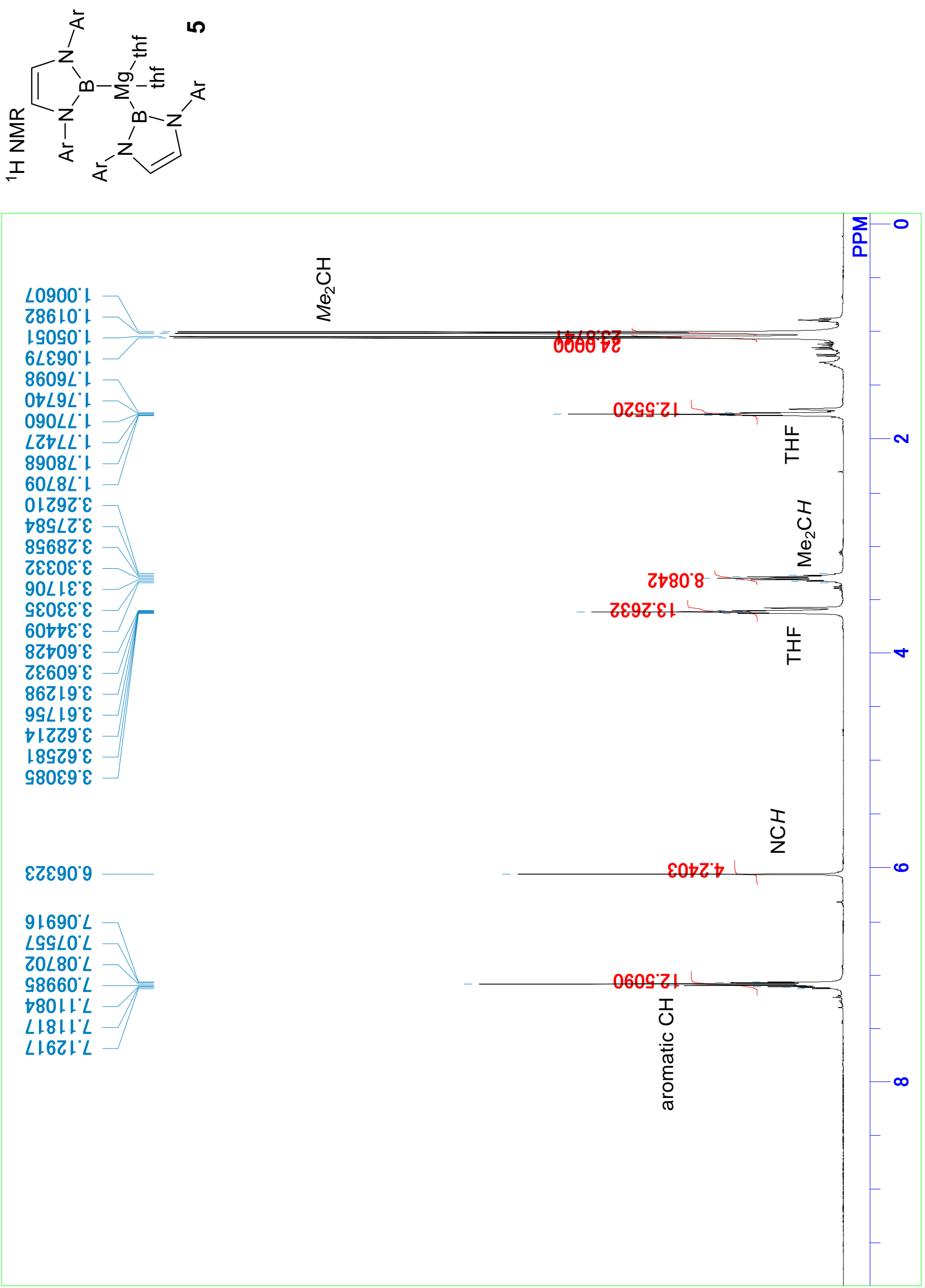

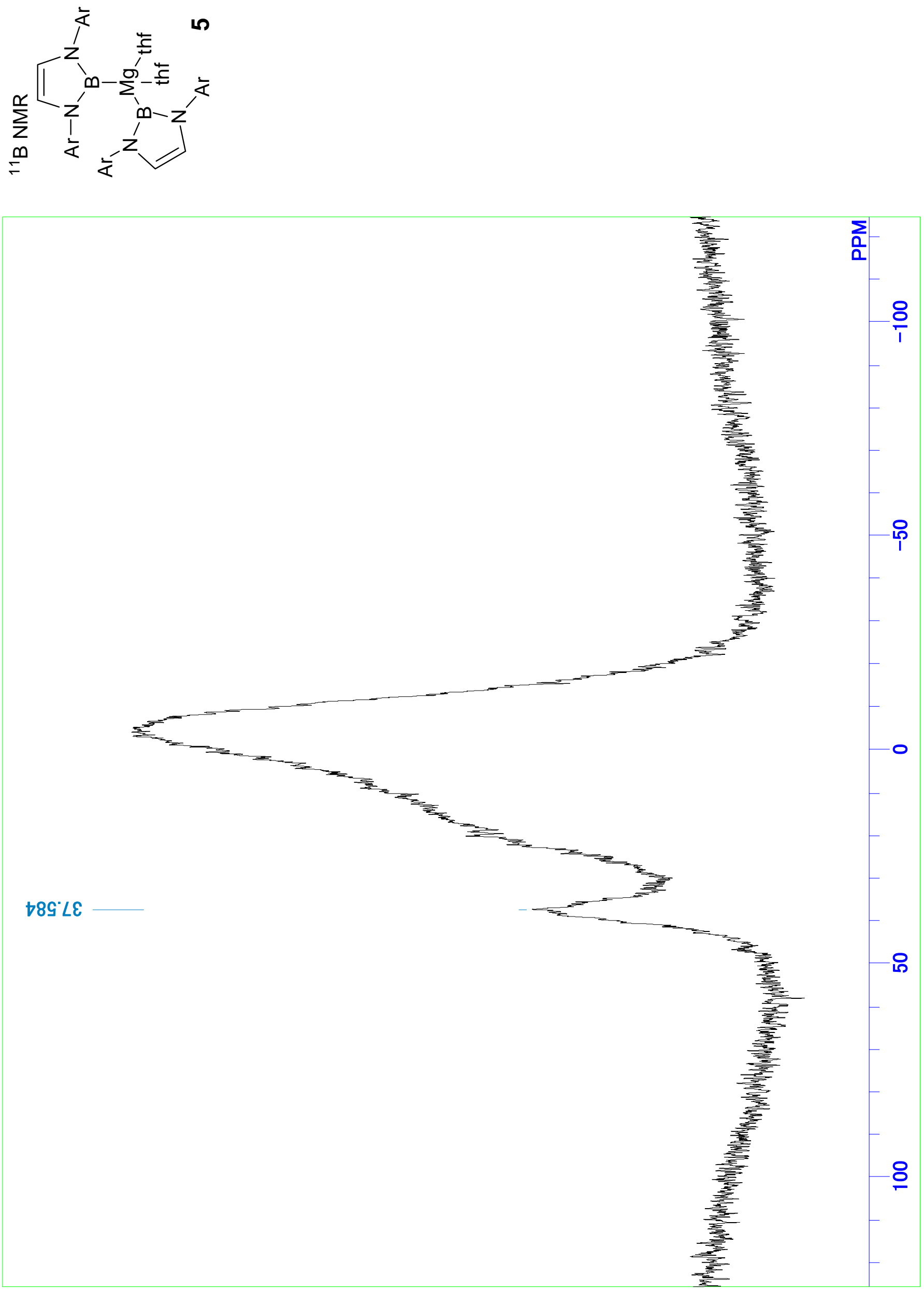

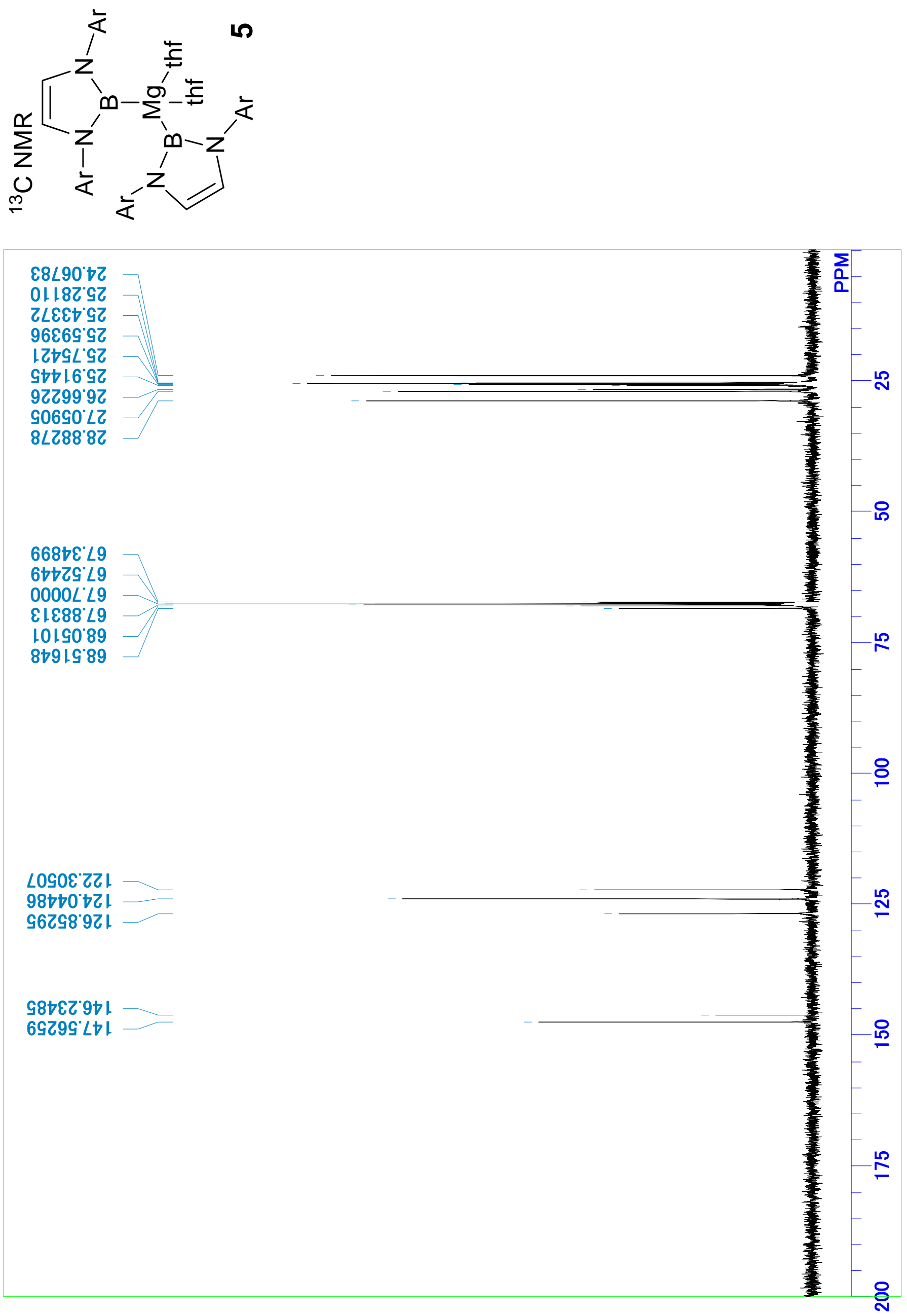